\title{
The Effect of Illegal Mining Activities on Vegetation: A Case Study of Bontefufuo Area in the Amansie West District of Ghana
}

Richard A. Kuffour*, Benjamin M. Tiimub, Isaac Manu and Wellington Owusu Department of Environmental Health and Sanitation Education, University of Education, Winneba, Ghana

$\begin{array}{cl}\text { Article History } & \text { Abstract: Background: The destruction of vegetation cover is among the main factors } \\ \text { Received: } 07.10 .2020 & \begin{array}{l}\text { contributing to climate variation. The study investigated the distribution of trees, shrubs } \\ \text { and herbs in the mined and unmined communities of Bontefufuo namely: Esaase, } \\ \text { Accepted: } 22.10 .2020\end{array} \\ \text { Published: } 15.11 .2020 & \begin{array}{l}\text { Manhyia, Aboabo and Mpatuam. The research was intended to determine the } \\ \text { relationship between the spatial distribution of vegetation, composition and examine the } \\ \text { effects of vegetation loss in the area. A total of forty } 40 \text { plots }(10 \mathrm{~m} \times 10 \mathrm{~m}) \mathrm{were}\end{array} \\ \text { Journal homepage: } & \begin{array}{l}\text { studied. In each community, five }(5) \text { plots were studied each for mined and unmined } \\ \text { areas. Results: The mean numbers of plant population were determined and analyzed } \\ \text { using ANOVA. There were significant differences among the tree, shrub and herb } \\ \text { populations at P<0.05. The number of shrubs and trees population was reduced in the } \\ \text { mined areas in relation to the areas that are not mined. Herbs were overwhelming within } \\ \text { the mined regions and were found to be much higher than within the unmined regions. } \\ \text { Photographic images showed that the practices of illicit small-scale mining contributed } \\ \text { to land destruction by compacting the topsoil and accumulation of laterites. Conclusion: } \\ \text { Climate change issues still remain a global concern and vegetation cover which plays an } \\ \text { imperative role in regulating the carbon dioxide concentration of the atmosphere should } \\ \text { be restored. } \\ \text { Keywords: Unmined area, mined area, herbs, shrubs, trees. }\end{array}\end{array}$

Copyright () 2020 The Author(s): This is an open-access article distributed under the terms of the Creative Commons Attribution 4.0 International License (CC BY-NC 4.0) which permits unrestricted use, distribution, and reproduction in any medium for non-commercial use provided the original author and source are credited.

\section{INTRODUCTION}

Artisanal mining is a significant subsector of the mining business in Ghana, accounting for about $10 \%$ of the annual gold output [1]. This includes activities of illegal mining and poses problems in Ghana to track and control small-scale mining practices. A United Nations (UN) research on artisanal and deprivation report estimates that there may be between 50,000 and 80,000 people engaged in illegal small-scale mining in Ghana [2].

While illegal mining undertakings have often made headlines for their destruction of the vegetation and the danger they pose to the lives of those engaged in it, very little investigation has been conducted to find out why people engage in it in spite of its dangers. These activities are clearly flourishing among rural poor, unemployed and groups of people with limited income-generating activities. Although it is illegal, dangerous and hostile to the development of the country, it is a source of income and livelihood for these people in the mining communities and over a million inhabitants there. To these rural folks, it is the only way to raise the needed capital to invest in facilities and equipment that make life worth living and to raise enough money to pay monthly bills. Undoubtedly, artisanal mining activity in Ghana has come to stay in view of the numerous economic and social benefits that it has bequeathed on the various communities, and for the fact that unemployment problem is on the ascendancy in the country.

Bontefufuo is an area in Amansie West District of Ashanti region which has tropical forest vegetation. The people are mainly cocoa farmers with a few of them being traditional gold miners from the colonial time. In spite of the economic gains accrue from their farming activities on the land, large hectares of land and its vegetative cover have been cleared as a result of surface mining activities. The forests reserves are the most seriously affected of these activities. These extensive mining activities have turned large areas of the communities into degraded land, creating habitat conditions unsuitable for plant growth. The numbers of species of trees and shrubs have dwindled considerably as a result of mining activities. Recent news stories in a segment of the Ghanaian media reported that there has been a steady and conspicuous degradation of over $80 \%$ of forest reserves in these mining communities which have also led to heavy pollution of rivers such as: Birim, Ankobra and Pra in Ghana [3]. Mining activity is 
one of the major factors accounting for environmental destruction. It creates a large chunk of debris on the land, open pits and destruction of land for farming and settlement. This has a major adverse effect on the soil and vegetation [4].

\section{Methodology \\ Location and size}

Bontefufuo is located in the Amansie West, one of the Districts in Ashanti region in Ghana. Amansie West District is surrounded by, Amansie East District, Atwima Mponua District, Atwima Nwabiagya District, and Amansie central District, in the west, east, north, and south respectively. The District falls within latitudes $6.05^{\circ}$ West and $6.35^{\circ}$ North and longitude $1.40^{\circ}$ South and $2.05^{\circ}$ West. The District has a land area of about 1,364 sq. Km, representing about $5.4 \%$ of the estimated land total land covered by Ashanti Region. The district has twelve (12) area councils, fiftythree (53) unit committees with 53 electoral areas, one constituency and one traditional council. Manso Nkwanta, which is located about $65 \mathrm{~km}$ south-west of Kumasi, is the District capital [5].

\section{Demography of Study Area}

With reference to 2010 national inhabitants' census and group's projections, the inhabitants in the District was estimated at 144,104 and the density estimated at 105 persons per sq. $\mathrm{km}$ at a growth rate of $2.9 \%$ between 1984 and 2010. Though the population density is comparatively lower than that of the region and national estimate of 127 and 212 persons per sq. $\mathrm{Km}$. respectively, the dispersed nature of settlement with low population density makes access to basic services difficult and expensive. About $80 \%$ of the population are Christians. The $0-14$ age cohorts constitute $41.9 \%$ of the total population whereas the age group 65 and above make up only 5.3\%. Thus the dependent population consisting of the total of the two age cohorts constitutes about $47.2 \%$ of the total population in the District [6].

\section{Natural Vegetation}

The District is completely located in the rain forest belt and desplays moist semi-deciduous features. It is much resourced with timber, herbs of medicinal value and fuelwood. However, the virgin forest cover has been degraded in several areas. Factors such as increased population, excessive and reckless logging for export and galamsey activities are responsible for the alarming rate of deforestation in the district. As a result, the typical forest cover of the district has been degraded and given way to secondary mosaic forest, shrubcovered land and agricultural holdings. It is only in areas, particularly those immediately outside the forest reserves in the District that traces of virgin forest are found. Main reserves of forest in the district are; the Apamprama forest, Gyeni river forest, Oda river forest and Jimira forest [6].

\section{Mineral Deposits in the District}

Potentially rich mineral (gold) deposits include the resources officially identifies in the district. Areas that were found with such deposit include; Esaase, Tetrem, Essuowin, Mpatuam, Mim, Agroyesum, Abore, Tontokrom etc. Some mining companies have been given license to do prospecting work on large hectares of land that have been acquired as concessions in the district. It is estimated that in the Jeni and Bonte rivers, there are approximately $21,361,400$ cubic meters of soil containing 5,209,866 grams of gold. There are many other interested parties in the mining industry besides the companies with large concessions in the district. There are many pockets in the district of small groups of illegal mining who use very primitive methods to extract gold, involving a large percentage of the youth in their activities. These different groups ' activities are not well monitored, regulated and organized to be captured as part of the district's overall development efforts package [6].

\section{Data Collection}

A randomised sampling block design coupled with observation and interviews with the artisanal mining operators to gather quantitative and qualitative data on the vegetation (trees, shrubs and herbs) and wild animals from the mined and unmined areas in communities namely; Esaase, Manhyia, Aboabo and Mpatuam of Bontefufuo area. A total of forty (40) plots $(10 \mathrm{~m} \times 10 \mathrm{~m})$ were studied in order to investigate the distribution of trees, shrubs and herbs. With reference to the literature of a Taxonomist [7, 4, 8], trees shrubs and herbs were observed and counted. In each community, five (5) plots were studied each for mined and unmined areas. The respective mean numbers of species of tree, shrub and herb of the unmined areas in all the four communities were identified and counted and compared to mean numbers of the same species in the mined areas of the communities. Some elderly people and leaders in the artisanal mining were interviewed about the nature of the wildlife before the start of the ongoing artisanal mining.

ANOVA on Microsoft Excel was used to test for significant differences among tree, shrub and herb species. Field observations and photographic images of degraded areas as a result of mining were captured for the study.

The different vegetation characteristics, distribution pattern, and other uses of the land related to forest and mining were examined.

\section{RESUlTS AND DisCUSSION}

Floristic Composition of Mined and Unmined Areas

The average number of trees and shrubs species within the areas mined reduced when compared to the unmined [19] areas while the average quantity of herbs increased in the areas mined compared to the unmined area (Figure 1). 


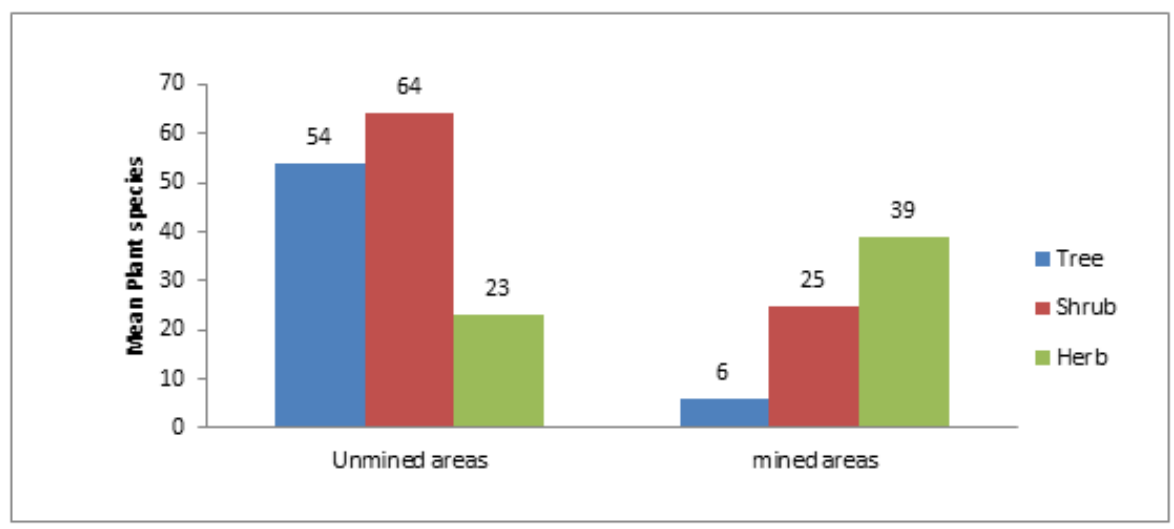

Fig-1: Mean Distribution of Plants in Unmined and Mined Areas

The average quantity of tree species per 100 $\mathrm{m}^{2}$ within the areas unmined was 54 while the mined areas in the towns recorded $4,7,3$, and 11 per $100 \mathrm{~m}^{2}$ plot for Esaase, Manhyia, Aboabo and Mpatuam respectively which were far lesser than the unmined area (Table 1). The shrub species recorded average quantity of 64 per plot in the unmined area while the areas mined recorded $19,25,22$, and 35 species per plot in Esaase, Manhyia, Aboabo and Mpatuam communities respectively (Table 1) which were comparatively lesser than the unmined area. The average number of herb species was 23 per plot in the unmined areas while the areas mined recorded 39, 41, 40 and 34 per plot for Esaase, Manhyia, Aboabo and Mpatuam respectively which were rather higher than the unmined area (Table 1).

Table-1: Mean distribution of plants composition in the four different mining towns.

\begin{tabular}{|c|c|c|c|c|c|}
\hline Plant distribution & Unmined Area & Esaase & Manhyia & Aboabo & Mpatuam \\
\hline Number of trees & 54 & 4 & 7 & 3 & 11 \\
\hline Number of shrubs & 64 & 19 & 25 & 22 & 35 \\
\hline Number of herbs & 23 & 39 & 41 & 40 & 34 \\
\hline
\end{tabular}

\section{Species Composition of Mined and Unmined Areas Trees and shrubs}

The number of tree species in the areas mined was extremely low in comparison to the areas unmined. The tree species density of 54 per $100 \mathrm{~m}^{2}$ in the unmined area compared to 6 per $100 \mathrm{~m}^{2}$ in the mined area was an indication of the level of destruction caused. The rate of degradation was far higher, compared with what was observed in the TalensiNabdam district in the northern region of Ghana [9] which was 2.4 per $100 \mathrm{~m}^{2}$ and 5.6 per $100 \mathrm{~m}^{2}$ for mined and unmined areas respectively. Small-scale gold mining exploits the required minerals by destroying the vegetative cover and the underlying soil [10].

The average number of species of shrub was also higher in the areas unmined than the mined areas. The quantities of shrub species per $100 \mathrm{~m}^{2}$ in the unmined and the mined areas were 64 and 25 respectively. This showed higher shrub density as compared to 1.6 per $100 \mathrm{~m}^{2}$ and 2.6 per $100 \mathrm{~m}^{2}$ for the mined and unmined areas identified in the Talensi Nabdam district in the north. Generally, the numbers of tree species in the mined areas of the four study communities were significantly lesser as compared to the number of tree species in the unmined areas. Again, the average quantity of species of shrub recorded in the areas mined was significantly lesser than those recorded in the unmined areas. The unmined area had greater plant species density compared to the mined areas.
Since the mined and the unmined places had almost the same climatic conditions, it was assumed that the density of the plant species in the mined areas just before they were cleared for mining activity and that of the unmined areas were equal and that the variations in the species numbers could be mainly linked to the mining activities.

The number of species of herbs was rather higher within the mined area than the unmined area. The average density was 23 per $100 \mathrm{~m}^{2}$ within the unmined areas while the mined areas had 39 per 100 $\mathrm{m}^{2}$. This showed an increase in number even in the mined area. This could be due to the fact that the mining activities had destroyed the tree and shrub species which usually overshadow the herbs and their seeds preventing them from the reach of sunlight. Therefore in their absence, there was maximum exposure to sunlight, allowing more of the herb species to start growing. However, the herbs observed at the mined areas were mostly young and small ones which had a comparatively negligible vegetative cover.

It can, therefore, be said that after clearing the land for mining activities, the land cover was dominated by fresh herbs with a few shrubs and trees remaining. In all the four study communities, the entire mining sites were observed to have more fresh herbs than the unmined sites (Tables 2, 3, 4 and 5). 
Table-2: Percentages of Species population at Esaase mining site

\begin{tabular}{|c|c|c|c|c|c|}
\hline \multirow{2}{*}{$\begin{array}{l}\text { Type of } \\
\text { Species }\end{array}$} & \multicolumn{2}{|c|}{ Esaase site } & \multirow{2}{*}{$\begin{array}{l}\text { Percentage } \\
\text { of the mine area }(\%)\end{array}$} & \multirow{2}{*}{$\begin{array}{c}\text { Variation } \\
\text { (Increase/Decrease) }\end{array}$} & \multirow{2}{*}{$\begin{array}{c}\text { Percentage } \\
\text { Variation } \\
\text { (Increase/Decrease) }\end{array}$} \\
\hline & $\begin{array}{l}\text { Unmined } \\
\text { area }\end{array}$ & $\begin{array}{l}\text { Mined } \\
\text { area }\end{array}$ & & & \\
\hline Trees & 54 & 4 & 7.4 & 50 (decrease) & 92.6 (decrease) \\
\hline Shrubs & 64 & 19 & 29.7 & 45 (decrease) & 70.3 (decrease) \\
\hline Herbs & 23 & 39 & 169.5 & 16 (increase) & 69.5 (increase) \\
\hline
\end{tabular}

Table-3: Percentages of Species population at Manhyia mining site

\begin{tabular}{|l|l|l|l|l|l|}
\hline \multirow{2}{*}{$\begin{array}{l}\text { Type of } \\
\text { Species }\end{array}$} & \multicolumn{2}{|c|}{ Manhyia site } & $\begin{array}{l}\text { Percentage of } \\
\text { mine area }(\boldsymbol{\%})\end{array}$ & $\begin{array}{c}\text { Variation } \\
\text { (Increase/Decrease) }\end{array}$ & $\begin{array}{l}\text { Percentage variation } \\
\text { (increase/Decrease) }\end{array}$ \\
\cline { 2 - 6 } & Unmined area & Mined area & 12.95 & 47 (decrease) & 87.05 (decrease) \\
\hline Tree & 54 & 7 & 39.07 & 39 (decrease) & 60.93 (decrease) \\
\hline Shrub & 64 & 25 & 178.2 & 18 (increase) & 78.2 (increase) \\
\hline Herb & 23 & 41 &
\end{tabular}

Table-4: Percentages of Species population at Aboabo mining site

\begin{tabular}{|c|c|c|c|c|c|}
\hline \multirow{2}{*}{$\begin{array}{l}\text { Type of } \\
\text { Species }\end{array}$} & \multicolumn{2}{|c|}{ Aboabo site } & \multirow{2}{*}{$\begin{array}{l}\text { Percentage of } \\
\text { the mine area } \\
\quad(\%)\end{array}$} & \multirow{2}{*}{$\begin{array}{c}\text { Variation } \\
\text { (Increase/Decrease) }\end{array}$} & \multirow{2}{*}{$\begin{array}{c}\text { Percentage variation } \\
\text { (increase/Decrease) }\end{array}$} \\
\hline & Unmined area & Mined area & & & \\
\hline Tree & 54 & 3 & 5.55 & 51 (decrease) & 94.45 (decrease) \\
\hline Shrub & 64 & 22 & 34.38 & 42(decrease) & 65.62 (decrease) \\
\hline Herb & 23 & 40 & 173.9 & 17 (increase) & 73.9 (increase) \\
\hline
\end{tabular}

Table-5: Percentages of Species population at the Mpatuam mining site

\begin{tabular}{|l|l|l|l|l|l|}
\hline \multirow{2}{*}{$\begin{array}{l}\text { Type of } \\
\text { Species }\end{array}$} & \multicolumn{2}{|c|}{ Mpatuam site } & $\begin{array}{l}\text { Percentage of } \\
\text { mine area (\%) }\end{array}$ & $\begin{array}{l}\text { Variation } \\
\text { (Increased/Decrease) }\end{array}$ & $\begin{array}{l}\text { Percentage } \\
\text { variation } \\
\text { (increase/Decrease) }\end{array}$ \\
\cline { 2 - 5 } & Unmined area & Mined area & & 43 (decrease) & 79.63 (decrease) \\
\hline Tree & 54 & 11 & 20.37 & $29($ decrease) & 45.31 (decrease) \\
\hline Shrub & 64 & 35 & 54.69 & 11 (increase) & 47.8 (increase) \\
\hline Herb & 23 & 34 & 147.8 & \\
\hline
\end{tabular}

Table-6: Average Plant Species Degradation

\begin{tabular}{|l|l|l|l|}
\hline & Tree (\%) & Shrub (\%) & Herb (\%) \\
\hline Esaase & 92.6 & 70.3 & 69.5 \\
Manhyia & 87.05 & 60.93 & 78.2 \\
Aboabo & 94.45 & 65.62 & 73.9 \\
Mpatuam & 79.63 & 45.31 & 47.8 \\
\hline Average & 88.42 & 60.54 & 67.35 \\
\hline
\end{tabular}

Using ANOVA at a significant level of 0.05 , there were significant differences among trees, shrubs and herbs found between the mined and unmined areas. P-value of 0.0029 was recorded among trees found between mined and unmined areas while P-values of 0.0096 and 0.0058 were recorded for shrubs and herbs between mined and unmined areas respectively.

\section{Species Diversity}

The diversity of species showed that trees and shrubs were comparatively lesser in the mined areas than in the unmined areas. The number of species of the trees was drastically reduced in the mined areas. Based on the fact that the mined and unmined areas were located in similar climatic conditions and edaphic features, any difference identified in species composition could be attributed to the mining activities [11], conducting studies on the impact of mining on vegetation characteristics concluded that vegetation reduces in mined areas compared with that of the adjacent unmined areas.

An overview of illegal mining sites in some of the communities showing Species diversity is shown in Plates 1 and 2.

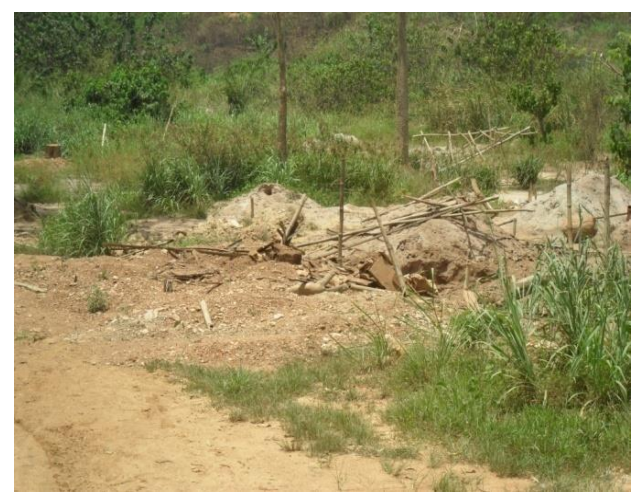

Plate-1: A mining site at Manhyia 


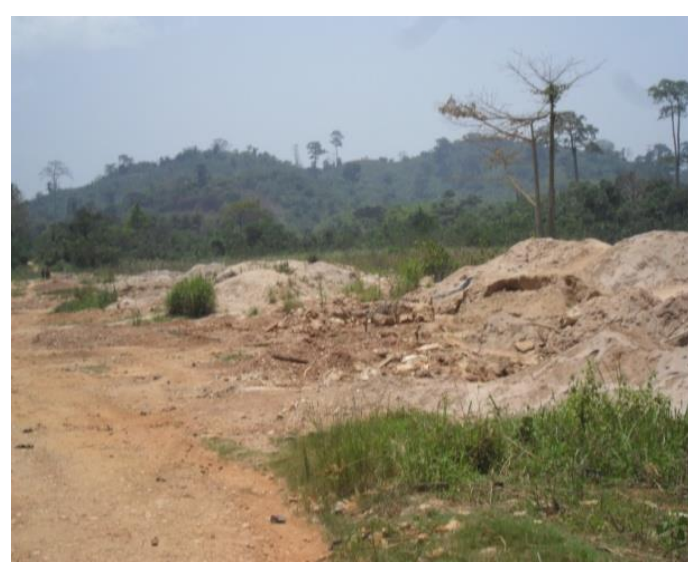

Plate-2: A mining site at Mpatuam

\section{Impact of mining activities on the species distribution pattern}

Plant population exhibit three patterns of spatial distribution that is clustered, random and regular. When determining how organisms should be used as a resource, the degree to which individuals are aggregated or dispersed is important. Research in natural resources utilization has proved that soil and water condition play major roles in controlling species distribution pattern, in the absence of major disturbances [12]. Most of the tree and shrub species, in the unmined areas showed a clustered pattern distribution. However, for the areas mined, the distribution showed a dispersed or scattered pattern. Numerous pits dug to win gold from the ore removed numerous plants at the gold-rich deposit areas. The dug laterite and washed gravel were also accumulated at the site contributing to the destruction of the plants.

\section{The Effect of Artisanal Mining Activities on Wildlife}

Wildlife species in communities depend on each other. Their survival depends on soil condition, local climate, altitude and vegetation. The destruction of plant species and its subsequent degradation (table 6) of the vegetation could be attributed to the degradation of the soil as a result of the illegal mining activities observed in the study. At the mining sites of the four communities, it was observed that the activities caused great destruction and displacement of the wildlife species. Their habitats were destroyed exposing them to unfavourable environmental conditions which impeded their growth and development. Information from the commuters indicated that wildlife species such as deer, antelope, monkeys, grasscutters, rats and tortoise were killed for food or destroyed by the miners while others migrated from the site. Most of these animals have migrated to different communities where there was enough vegetation to support their growth and development. Animals which were found at the mining sites were egrets, pie crow, lizards, owls, bats and some insects. Streams that provided habitat for the aquatic lives had been polluted with mud and laterite accumulation.

\section{Degradation of land}

Research by $[4,8]$, described that small-scale gold mining has been identified as gaining global prominence as both a source of livelihood for the poor and a cause for environmental degradation. Mining activity often causes regular destruction of farmland without adequate compensation for the farmers affected $[13,1]$.

According to personal observation made at the four communities, one of the major effects of surface mining was land degradation. Heavy machines were used for the removal of the vegetation, topsoil, and subsoil at some parts of the communities whereas most of the artisanal miners used indigenous tools to dig pits for the exploitation of the ore. A research by Anane, [14] alluded to the fact that surface mining, in particular, requires the clearance of large tracts of forest and agricultural land, resulting in significant land and forest degradation. Changes in the nature of vegetation cover, especially from forest to non-forest, may significantly change the budget for surface moisture and have a further effect on the budget for surface energy [15]. In some places, rocks, laterites and other debris from mining operations had covered the ground. The above stated materials had not only impeded plant growth on the ground but also covered the topsoil, thus creating unfavourable conditions which made it impossible for the germination of seeds of plants and their development.

In addition, it was observed that pits and trenches were created which eventually rendered such areas inaccessible to the people, while making it dangerous to wildlife. Depths of some pits observed ranged from about $10 \mathrm{~m}-20 \mathrm{~m}$ deep. Even where such pits were backfilled, they were rather covered with rocks and gravels. These could render the land infertile for plant growth and unsafe for agricultural purposes. Plates 3, 4, 5, and 6 show the degradation of land caused by the activities of Illegal mining in the study areas.

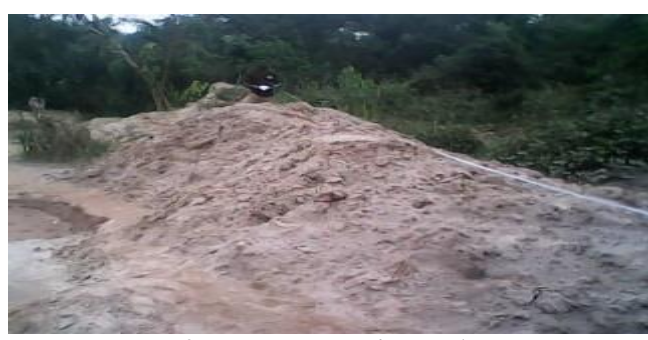

Plate-3: Heaped Laterites at Aboabo

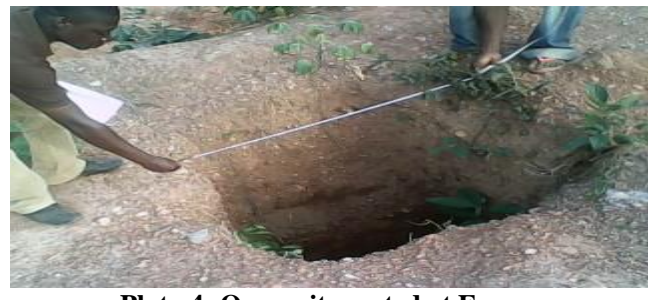

Plate-4: Open-pit created at Esaase 


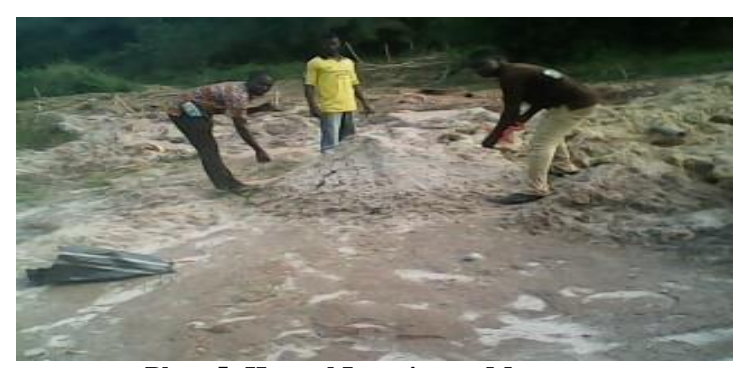

Plate-5: Heaped Laterites at Mpatuam

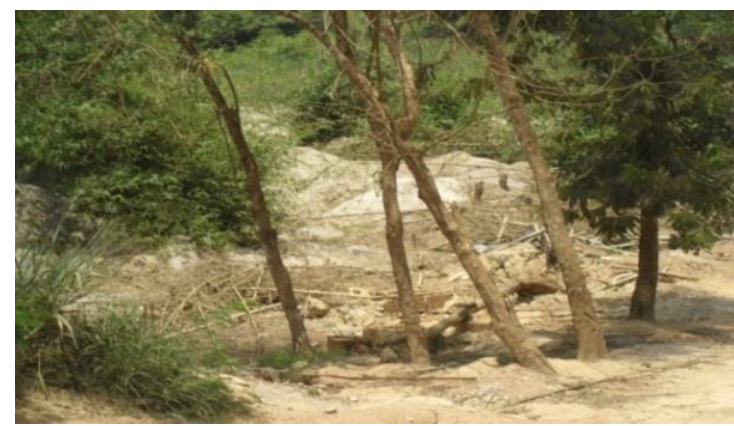

Plate-6: Land Degraded at Manhyia

\section{Deforestation and Climate Change}

Deforestation is a key contributory factor in global climate change. It is evaluated that more than 1.5 billion tons of carbon dioxide are discharged to the environment because of deforestation, fundamentally the cutting and ignition of timberlands, consistently. However, the impact of activities like artisanal mining that seriously contribute to vegetative cover destruction cannot be overemphasized. Enormous scale changes in vegetation spread for instance decrease in the forest cover would be relied upon to alter the local climate. Reduction of the forest cover will contribute to climate change by releasing accumulated carbon that leads to the rise of carbon dioxide in the atmosphere [15]. The average vegetation degradation of 88.42 and 60.54 percentages for the trees and shrub species respectively, obtained from the studies in the communities could make a meaningful contribution to climate change [16]. Therefore the illegal mining in the Bontefufuo that has destroyed a large amount of vegetative cover could be a contributor to climate change due to buildup of carbon dioxide in the atmosphere. The continuous destruction of the vegetation would reduce the potential of plants to use the excess carbon dioxide while the exposed soil would also increase the release of carbon dioxide into the atmosphere.

Every year more than 30 million acres of forests and farmland are lost due to deforestation; resulting in a massive loss of income for poor people living in remote areas who rely on the forest to survive [17]. Severe flooding is a result of deforestation due to removal of the forest leaves little vegetative cover to hold heavy rains. The deforestation by the illegal mining activities contributes to the compaction of the topsoil restricting the release of nutrients to the plant for growth.
The excess water from land cleared of the forest becomes runoff water and enters the ocean instead of seeping down into the soil to recharge aquifers. Aquifer depletion is already becoming a serious problem in certain areas of the planet and as the human population continues to grow so will the demand for freshwater [18].

\section{CONClusion AND RECOMMENDATIONS Conclusion}

The study showed that mining activities have resulted in the reduction of vegetation cover in Bontefufuo area. Generally, in all the four mining towns, the number of trees and shrubs were reduced compared to those in the unmined area. The average tree cover in the mined areas of Bontefufuo was reduced by $88.42 \%$ in the illegally mined areas. The average shrub cover in the mined areas of Bontefufuo was reduced by $60.54 \%$ in the illegally mined areas. Though the herb population increased in the mined area, their cover was almost negligible since their sizes were so small to make an impact in terms of vegetation cover. The accumulated gravels and laterites spread on the soil coupled with compaction of the soil through human movements prevented the growth of vegetation. The forest removes carbon dioxide from the atmosphere through photosynthesis; therefore vegetation degradation through illegal mining in the Bontefufuo would contribute to declining in photosynthetic activity resulting in higher levels of carbon dioxide in the atmosphere.

\section{Recommendations}

In order to curb the issue of vegetation degradation through illegal mining, the following recommendations were made:

- The Environmental Protection Agency should institute measures to regulate the activities of illegal mining to avoid further destruction to the environment and its vegetation.

- The forestry department of Amansie West District should embark on education to sensitize the rural folks about the detriments of mining activities on their health and the environment.

- Stringent and thorough endeavours at reafforestation of influenced networks and different measures planned for re-establishing debased terrains to their unique state subsequent to mining exercises ought to be strengthened by the Forestry Department in the District. These will make land accessible especially to ranchers for rural purposes.

- Further studies needed to be conducted to estimate the volume of vegetation lost per unit area and carbon dioxide released as a result of the loss. 


\section{DECLARATION}

- Ethics approval and consent to participate Not applicable

\section{- Consent for publication}

The consent of all authors were sought before submitting this manuscript for publication.

\section{- Availability of data and materials}

All necessary data collected and used for the study have been included in the article.

\section{- Competing interests}

There is no conflict of interest with respect to the publication of this paper.

\section{- $\quad$ Funding}

This study was self-funded

\section{- Authors' contributions}

Richard A. Kuffour: Lead author who designed and supervised the research and did the write up of the manuscript. Benjamin M. Tiimub: Cosupervisor who contributed to the write-up of the manuscript. Isaac Manu: Contributed to the field data collection. Wellington Owusu: Contributed to the field data collection and data analyses.

\section{ACKNOWLEDGEMENTS}

Some individuals who contributed to the success of this paper included Mr Gadafi Iddrisu Balali Department of Theoretical and Applied Biology, Kwame Nkrumah University of Science and Technology who assisted in formatting and editing the paper, Filed data collectors, Isaac Manu and co are hereby all acknowledged by the author for their profound support and contributions. The study was selffunded.

\section{REFERENCES}

1. Akabzaa, T., \& Darimani, A. (2001). Impact of mining sector investment in Ghana: A study of the Tarkwa mining region. Third World Network, 47-61.

2. Yeboah, J. Y. (2008). Environmental and health impact of mining on surrounding communities: a case study of Anglogold Ashanti in Obuasi.

3. Asamoah, E. (2012). The Impact of Small Scale Gold Mining Activities on the Water Quality of River Birim in the Kibi Traditional Area.

4. Kuffour, R. A., Tiimub, B. M., \& Owusu Wellington, M. I. (2013). The Effect of Illegal Mining Activities on Vegetation: A Case Study of Bontefufuo Area in the Amansie West District of Ghana. Conference Proceedings, Organisation of Women in Science for the Developing World (OWSD) Africa Regional Conference from Tuesday, October 15-18, 2013 in
Sunyani.Mercy Derkyi Esi Awuah Daniel ObengOfori Nana Sarfo Agyemang Derkyi Fred OwusuAnsah, 721.

5. Apam, S. (2014). Impacts of small scale mining on rural livelihoods: The case study of Amansie West District-Ashanti. Kwame Nkrumah University Of Science And Technology, Kumasi.

6. Antwi, B. B. (2014). Galamsey as a livelihood approach in Ghana.

7. Kuffour, R. A., Tiimub, B. M., \& Agyapong, D. (2018). Impacts of illegal mining (galamsey) on the environment (water and soil) at Bontefufuo area in the Amansie West district. J Environ Earth Sci, 8(7), 98107.

8. Kyermeh, S. (2004). Management of Environmental Impacts of Gold Mining in Southern Ghana. University of Stirling (United Kingdom).

9. Tom-Dery, D., Dagben, Z., \& Cobbina, S. (2012). Effect of illegal small-scale mining operations on vegetation cover of arid northern Ghana. Research journal of environmental and earth sciences, 4(6), 674-679.

10. Gyampoh, O. A. (2013). Impact Assessment of Small Scale and Illegal Mining Activities-A Case Study of Birim River in Kyebi, East Akim Municipality.

11. Sarma, K. (2005). Impact of coal mining on vegetation: a case study in Jaintia Hills district of Meghalaya, India.

12. Ashton, P. S. (1989). Species richness in tropical forests.

13. Akabzaa, T., Banoeng-Yakubo, B., \& Seyire, J. (2005). Impact of mining, Tarkwa, a mining Community. Bull. Env. Conta. Tox, 79, 377-379.

14. Anane, M. (2003). Gold discovered beneath Ghana's forest reserves'. News-Letters, Environment News Service (ENS), 4.

15. Betts, R., Sanderson, M., \& Woodward, S. (2008). Effects of large-scale Amazon forest degradation on climate and air quality through fluxes of carbon dioxide, water, energy, mineral dust and isoprene. Philosophical Transactions of the Royal Society B: Biological Sciences, 363(1498), 1873-1880.

16. Pedrolo, A. M., Stafen, C. F., Leitzke, S., Viana, V. E., Busanello, C., da Rosa, M. P., .. . Pegoraro, C. (2019). Efeitos de ácidos orgânicos na germinação e crescimento inicial de Brassica napus L. var. oleifera. Revista de Ciências Agroveterinárias, 18(2), 163-169.

17. Chivian, E., \& Bernstein, A. (2008). Sustaining life: how human health depends on biodiversity: Oxford University Press.

18. Homer-Dixon, T. F. (1994). Environmental scarcities and violent conflict: evidence from cases. International Security, 19(1), 5-40.

19. Control, C. f. D., \& Prevention. (2008). National diabetes fact sheet: general information and national estimates on diabetes in the United States, 2007 Atlanta, GA: US Department of Health and Human Services, Centers for Disease Control and Prevention, 1 . 